\title{
Melanoma vaccines and modulation of the immune system in the clinical setting: building from new realities
}

\section{Florencia Paula Madorsky-Rowdo ${ }^{1}$, María Laura Lacreu ${ }^{1}$ and José Mordoh ${ }^{1,2 *}$}

${ }^{1}$ Laboratorio de Cancerología, Fundación Instituto Leloir, IIBBA-CONICET, Buenos Aires, Argentina

${ }^{2}$ Centro de Investigaciones Oncológicas, Fundación Cáncer and Instituto Alexander Fleming, Buenos Aires, Argentina

\section{Edited by:}

Brian J. Czerniecki, University of

Pennsylvania, USA

\section{Reviewed by:}

Fabio Bagnoli, Novartis Vaccines, Italy Sylvie Fournel, Strasbourg University,

France

*Correspondence:

José Mordoh, Laboratorio de Cancerología, Fundación Instituto Leloir, Av. Patricias Argentinas 435, 1405 Buenos Aires, Argentina. e-mail: jmordoh@leloir.org.ar
To endow the immune system with the capacity to fight cancer has always attracted attention, although the clinical results obtained have been until recently disappointing. Cutaneous melanoma is a highly immunogenic tumor; therefore most of the attempts to produce cancer vaccines have been addressed to this disease. New advances in the comprehension of the mechanisms of antigen presentation by dendritic cells, in the immune responses triggered by adjuvants, as well as the understanding of the role of immunosuppressor molecules such as cytotoxic T-lymphocyte antigen-4 (CTLA-4), which led to the recent approval of the anti-CTLA-4 monoclonal antibody ipilimumab, have opened new hopes about the installment of immunotherapy as a new modality to treat cancer.

Keywords: cancer vaccines, immunotherapy, CTLA-4, melanoma
The human immune system is highly elaborated, with a diversity of stop and go mechanisms necessary to accomplish different tasks, encompassing clear "stop" situations, such as those needed to avoid fetal rejection during pregnancy, and permanent "go" status, necessary to combat infections by virus, bacteria, or fungi. Both mechanisms are in place or may be activated in a healthy organism, and distinction of "self" and "foreign" is essential to accomplish these tasks. Being cancer a disease generated by autologous cells, is it possible to teach the organism to fight it? In this review, which does not intend to be exhaustive, we shall discuss some of the most explored fields of research which aim to fight cancer through stimulating or inhibiting some specific targets of the immune system.

\section{IMMUNE STIMULATION BY CANCER VACCINES}

The rationale of using therapeutic vaccines in cancer began in the 1950s, when the fact that tumors express specific antigens (Ag) was demonstrated (Foley, 1953; Prehn and Main, 1957). Thus, immunity to cancer might be acquired, and the idea of developing cancer vaccines started. Most of the work in this field was performed on cutaneous melanoma (CM), which originates from melanocytes, melanin-containing cells that are responsible for pigmentation and protection against UV DNA damage, and it is a tumor with rising incidence worldwide (Siegel et al., 2012). Although CM is curable by surgical resection if detected in the early stages (Breslow Index $<2 \mathrm{~mm}$ depth), once it metastasizes its prognosis worsens, and it is refractory in the long-term to most current therapies (Gray-Schopfer et al., 2007). Different lines of evidence suggested that CM is an immunogenic tumor, mainly demonstrated by the existence of regressions in primary tumors and by the correlation between the presence of "brisk" lymphocytic infiltrates in primary tumors and longer survival (Clemente et al., 1996). Early work on CM vaccines was performed by Morton et al. (1968, 1970), Seigler et al. (1975), and by Berd and Mastrangelo (1988a,b), who used autologous irradiated melanoma cells as vaccines. After these pioneer attempts, several melanocytic differentiation $\mathrm{Ag}$ (MD-Ag) were discovered, such as MelanA/MART-1 (MART-1; Coulie et al., 1994; Kawakami et al., 1994a), gp100/PMEL17/silver (gp100; Kawakami et al., 1994b), tyrosinase (Brichard et al., 1993); tyrosinase-related protein-2 (trp-2; Wang et al., 1996), MELOE-1 (Godet et al., 2008), and a group of cancer-testis Ag (CT-Ag), such as the MAGE super-family and NY-ESO-1 (van der Bruggen et al., 1991; Chen et al., 1997). Besides these Ag, recent genomic work performed in human CM revealed dozens of mutations present in the melanoma genome, many of them residing in exons (Chin et al., 2006; Dutton-Regester and Hayward, 2012). The development of new high-throughput technologies, such as next-generation sequencing, will lead to a better knowledge of the battery of mutations present in different types of cancer and, particularly, in each patient. Somatic mutations that occur with very low frequencies may be detected, as well as other types of aberrations, including translocations and epigenetic changes (Ross and Cronin, 2011). Castle et al. (2012) identified somatic point mutations in B16F10 murine melanoma cell line using next-generation sequencing. Immunogenicity of 50 validated mutations was assayed by immunizing mice with peptides encoding for the mutated epitopes, founding that one third of them were immunogenic.

Therefore, and considering the failure of most chemotherapeutic treatments, immunotherapy presents as a promising option. Until recently, the still fully unanswered question was whether humoral or cellular immune response would be more convenient to eradicate tumors in general and CM in particular. In a phase III randomized clinical study performed in $880 \mathrm{CM}$ patients, a vaccine of GM2 ganglioside coupled to Keyhole Limpet Hemocyanin and using QS-21 as adjuvant, which induced IgM and IgG antibodies, was compared with high-dose interferon-alfa. The vaccination arm did worse than the interferon arm, and the assay was interrupted before completion (Kirkwood et al., 2001). However, when the effort was placed in the stimulation of cellular immunity, 
initial results were also disappointing. Thus, several clinical trials in stages IIB-IV CM patients utilizing vaccination with multiple peptides derived from MD-Ag (MART-1, gp100, and tyrosinase), and from CT-Ag (MAGE), had also limited success in CM patients (Rosenberg et al., 2004; Terando et al., 2007; Slingluff et al., 2008). It appears clear therefore that the optimal delivery of tumor Ag, in the presence of appropriate adjuvants, has not yet been found. In view of the multiplicity of possible Ag present in CM, mutated, and non-mutated, an approach has been to use vaccines consisting of irradiated whole tumor cells, which contain most of tumor Ag, giving the immune system the opportunity to process all of them (Barrio et al., 2006; von Euw et al., 2007, 2008). The rationale assumption is that vaccination with a single or a few tumor Ag would not be sufficient to eradicate tumors, even if CD8+ and CD4+ cells are generated and are efficient in killing Ag-positive tumor cells, since we and others have shown that Agnegative cells are present in most primary and metastatic CM and would soon repopulate the tumor (Koebel et al., 2007; Aris et al., 2012). The original approach of using autologous cells as vaccines (Berd and Mastrangelo, 1988a) has two major disadvantages: first, patients must have heavy metastatic disease to obtain enough cells after surgery to manufacture vaccines, and are therefore relatively advanced stage of the disease; second, reproducibility in vaccine preparation is difficult to attain, since different patients have different tumor masses and cell yields are quite diverging. A significant advance in the vaccination field was achieved when it was demonstrated that the addition of the cytokine GM-CSF to vaccines increased the immune response against tumors (Dranoff et al., 1993). Several clinical trials have thereafter used GM-CSF to increase immunogenicity. Luiten et al. (2005) used autologous melanoma cells transduced with a GM-CSF-producing retrovirus, and observed in some patients that tumor sites became infiltrated with lymphoid cells. Also, Soiffer et al. (2003) used as vaccines irradiated autologous melanoma cells transduced with an adenovirus containing the GM-CSF gene. In this trial, immune reactivity at tumor sites was also observed, but all tested patients developed anti-adenovirus antibodies. We therefore decided to use as therapeutic vaccine a mixture of irradiated allogeneic melanoma cell lines, with BCG as adjuvant and injecting at the vaccination site GM-CSF coincidently with the vaccines; in this way we could exactly determine the amount of injected GM-CSF, and thus avoid the uncertainty of the amount and length of GM-CSF production by irradiated tumor cells. Using this approach in a Phase I clinical trial including $20 \mathrm{CM}$ patients in stages III and IV, we obtained $70 \%$ of relapse-free survivors in stage III CM patients after a median follow-up of 106 months (Barrio et al., 2006). A similar vaccine (CSF 470) is now being assayed in a randomized Phase II/III clinical study, in which CSF470 plus GM-CSF and BCG as adjuvants is compared with IFN-alfa in stages IIB, IIC, and III CM patients.

The overall evidence has been shifting to the concept that immunity against CM should rely more on the development of specific CD8 and CD4 cells rather than on antibodies. The rationale of vaccination with tumor $\mathrm{Ag}$, either in the form of $\mathrm{Ag}$ peptides, whole tumor cells, or cell lysates, is that such Ag should be captured by dendritic cells (DC), first described by Steinman and Cohn (1973) in murine lymphoid organs, and later found to be potent stimulators of naïve lymphocytes (Steinman and
Witmer, 1978). Subsequent work demonstrated that DC participate in the afferent and efferent limbs of the immune response, each requiring Ag presentation and $\mathrm{MHC}$ restriction. When studying Langerhans cells, a distinct type of DC present in epidermis, Schuler and Steinman (1985) demonstrated that DC may exist in two states: immature DC, which are able to phagocytose Ag but not to process and present them to naïve lymphocytes, and mature DC, which have lost the ability to capture Ag but present processed Ag with great efficacy. The generally accepted pathways that DC use to activate naïve lymphocytes involves several steps: (i) capture of $\mathrm{Ag}$ in the periphery; (ii) maturation and migration of DC to draining lymph nodes; (iii) settling of DC in the lymph nodes and activation of naïve lymphocytes. Some of these steps have been analyzed to some detail in mice, although evidence in humans is still lacking. Thus, Eggert et al. (1999) demonstrated that only about $1 \%$ of subcutaneously injected DC migrate to lymph nodes, although resident Langerhans cells, after immunization in vivo, migrate in high numbers to lymph nodes and persist there for about 2 weeks (Garg et al., 2003). It may be thus concluded that in vivo migration of DC is substantially more efficient than migration after DC production in vitro and subcutaneous injection, which could hamper vaccination attempts with DC loaded with tumor Ag. After this scarce migration of injected DC to regional lymph nodes, they must still overcome another difficulty: to find the appropriate T cells expressing the adequate TCR while maintaining bound to their HLA molecules the Ag peptides long enough to induce long-lasting contacts (Hugues et al., 2004). In fact, a clinical study comparing DC charged with tumor peptides or cell lysates demonstrated that only the latter were capable of inducing immune responses (Hersey et al., 2004). An explanation for these results came recently, since it has been shown that Ag peptides induced a quicker and stronger, but less prolonged response, than larger Ag peptides that are taken up by DC and degraded inside the cells (Faure et al., 2009). Recently, several approaches have taken profit of the ability of DC to capture foreign Ag, among them tumor Ag, and present them to naïve lymphocytes (Goldszmid et al., 2003; Liu et al., 2005). In humans, Palucka et al. (2006) demonstrated that autologous DC were able to capture killed cells from an allogeneic tumor cell line and induce CD8+ $\mathrm{T}$ cell responses in 20 stage IV CM patients, leading to one complete and one partial response. Our group has demonstrated that autologous DC could capture a mixture of apoptotic and necrotic allogeneic melanoma cells, subsequently mature and cross-present MD-Ag to CD8 T cell clones (von Euw et al., 2007). von Euw et al. (2008) also performed a clinical study in CM patients demonstrating that up to $1 \%$ anti-MART- 1 and anti-gp100 CD8 T cell lymphocytes could be found in circulating blood after vaccination. Although $80 \%$ of Stage III patients attained a disease-free survival longer than 116 months, all stage IV patients relapsed. None of the approaches used so far could demonstrate that injected DC charged with apoptotic/necrotic tumor cells in humans are able to migrate efficiently to draining lymph nodes and establish a correct communication with naïve lymphocytes. The duration of the in vivo tumor Ag exposure by DC has also not been thoroughly studied in humans, as well as the number of CD8 cytotoxic T cells formed. A selection of different completed phase III clinical trials consisting in immunotherapeutic approaches against melanoma is shown in Table 1. 
Table 1 | Immunotherapies against cancer: completed phase III clinical trials in CM.

\begin{tabular}{|c|c|c|c|c|c|c|}
\hline & Type of treatment & Type of cancer & $\begin{array}{l}\text { Clinical trial } \\
\text { phase }\end{array}$ & Adjuvants used & $\begin{array}{l}\text { Clinical results } \\
\text { obtained }\end{array}$ & Reference \\
\hline \multirow{12}{*}{ 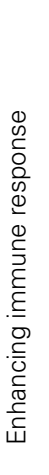 } & \multicolumn{6}{|l|}{ Ganglioside vaccine } \\
\hline & GMK vs. high-dose & Melanoma stages IIb/III & III & KLH - OS-21 & PFS and OS benefit & Kirkwood et al. \\
\hline & IFN-alpha2b (HDI) E1694 & & & & with HDI vs. GMK & $(2001)$ \\
\hline & \multicolumn{6}{|l|}{ Peptide vaccines } \\
\hline & Gp100 vaccine + high dose & Melanoma stage IV and & III & IFA (Montanide & Longer PFS vs. high & Schwartzentruber \\
\hline & IL-2 vs. high dose IL-2 & unresectable stage III & & ISA 51) & dose IL-2, no significant & et al. (2011) \\
\hline & NCT00019682 & & & & improvement in OS & \\
\hline & Vitespen (autologous & Melanoma stage IV & III & None & No changes in OS vs. & Testori et al. (2008) \\
\hline & tumor-derived heat shock & & & & physician choice & \\
\hline & protein gp96 peptide complex & & & & & \\
\hline & vaccine) NCT00039000 & & & & & \\
\hline & \multicolumn{6}{|l|}{ Whole cell vaccines } \\
\hline \multirow{9}{*}{ 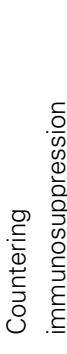 } & Canvaxin + BCG vs. & Melanoma stage IV & III & BCG & No change in OS vs. & Commented in \\
\hline & placebo + BCG NCT00052156 & & & & BCG & Sondak et al. (2006), \\
\hline & CTLA-4 & & & & & Dalgleish (2011) \\
\hline & Ipilimumab vs. & Melanoma stage IV and & III & IFA (Montanide & Improved OS & Hodi et al. (2010) \\
\hline & Ipilimumab + gp100 vs. gp100 & unresectable stage III & & ISA-51) in vaccine & ipilimumab alone or & \\
\hline & NCT00065442 & & & groups & +gp100 vs. gp100 alone & \\
\hline & Ipilimumab + dacarbazine vs. & Melanoma stage IV and & III & None & Longer OS with ipili- & Robert et al. (2011) \\
\hline & placebo + dacarbazine & unresectable stage III & & & mumab + dacarbazine & \\
\hline & NCT00324155 & & & & & \\
\hline
\end{tabular}

PFS, progression free survival; OS, overall survival.

Up to date, the only vaccine approved for cancer treatment is Provenge (sipuleucel- $\mathrm{T}$ ), a vaccine for advanced prostate cancer which consists of a mixture of peripheral blood mononuclear cells exposed to prostatic acid phosphatase fused to GM-CSF. In a phase III clinical trial, the use of Provenge prolonged overall survival in patients with metastatic castration-resistant prostate cancer (Kantoff et al., 2010), but no effect on time to disease progression was observed. Provenge hypothesized mechanism for antitumor activity is that Ag-presenting cells (APC) process and present the recombinant Ag on their surface. After being reinfused into the patient, these cells could activate $\mathrm{T}$ cells that recognize the specific Ag and, therefore, stimulate them to attack prostatic acid phosphatase-positive prostate cancer cells (Sonpavde et al., 2012). This proposed mechanism requires further validation. There are several critiques to this vaccine related with the fact that improved overall survival was not accompanied with measurable antitumor effect and with the lack of supportive evidence for the mechanism proposed. After reanalysis of phase III data and of previously unpublished data obtained from FDA documents, Huber et al. (2012) made some concerns about this recently approved vaccine. In the first place, unexpected interactions between patient age and survival were found: an 11-month difference in median overall survival between placebo patients younger and older than 65 years was observed, and sipuleucel- $T$ treatment appeared to have only a positive effect in survival of older patients. These results were unexpected because age is not a prognostic factor in castration-resistant prostate patients under chemotherapeutic treatment and immunotherapies should be more effective in younger patients. Other important point is that patients in the placebo group appeared to have shorter overall survival than might be expected from other studies, which led to think that placebo treatment is actually an inappropriate control for sipuleucel-T. Huber et al. also discussed the manufacture protocol of the vaccine and the placebo, suggesting that the placebo protocol included steps that could contribute to cell killing and therefore, injection of dead cells in patients of the placebo arm could lead to a reduction in overall survival (OS).

Besides this vaccine in particular, the reasons that could explain why therapeutic cancer vaccines do not act as well as expected are multiple. Finding the right adjuvants and countering immunosuppression are possible keys to bypass such limitations.

\section{ADJUVANTS}

A successful vaccination requires the addition to the desired $\mathrm{Ag}$ of adjuvants, which serve as amplifiers of the immune response. Adjuvants for clinical use must equilibrate efficacy with safety, although this balance should also integrate the purpose of vaccination: it is not the same scenario to vaccinate preventively millions of people against a viral disease such as influenza, than to vaccinate therapeutically a much more limited population with cancer, as would be the case of CM patients. In the latter case, a certain degree of toxicity of the adjuvants could be tolerated if the antitumor effect of vaccines is enhanced. We are still largely ignorant of the mechanism of action of adjuvants. The extremely potent complete Freund adjuvant (CFA) and incomplete Freund adjuvant (IFA) have been used for decades (Freund, 1956), but in spite of their potency, their use is not allowed in humans due to toxicity, since they may lead to harmful local injuries and 
autoimmune diseases. Essentially, IFA is paraffin oil suspended in water, and in addition, CFA contains heat-killed Mycobacteria, usually $M$. tuberculosis. Although used by immunologists for decades, the mechanisms of action of IFA and CFA are barely understood and are still being analyzed (Billiau and Matthys, 2001). Since IFA and CFA are potent but toxic, mineral oil has been replaced by terpenoids, among them the lipophilic substance squalene, a triterpene found in the adjuvants MF59 and AS03. Both have been used in clinical trials with a good safety profile and have been approved in Europe and conditionally approved in the US as stockpiled adjuvants in the pandemic influenza (Fox et al., 2011). Montanide ${ }^{\mathrm{TM}}$ incomplete Seppic adjuvant (ISA) 51 and 720 are water-in-oil emulsions similar to IFA that are under investigation for their use in humans. Montanide ${ }^{\mathrm{TM}} \mathrm{ISA} 51$ contains a mannide monooleate emulsifier and a degradable mineral oil, which has been demonstrated to be non-carcinogenic, nonteratogenic, and non-mutagenic. To improve safety, the mineral oil has been switched in Montanide ${ }^{\mathrm{TM}}$ ISA 720 to the metabolizable squalene oil (Aucouturier et al., 2006).

Also, QS-21, a water-soluble triterpene glycoside, has been used in clinical trials (Soltysik et al., 1995; Livingston et al., 1997; Kensil and Kammer, 1998). Novel isoprenoid immunostimulants, such as those phytol-derived, are also being analyzed (Chowdhury and Ghosh, 2012).

Aluminum salt/gel-based (Alum) adjuvants are approved for clinical use in the US and have been used for many years as immunopotentiator for vaccines, being particularly effective to promote protective humoral immunity (Schijns and Lavelle, 2011). However, Alum adjuvants do not induce a T helper type 1 cell-mediated immune response.

A great input to understand the mechanism of action of adjuvants came after the seminal finding by Hoffman's group of the immune function of Toll receptors in flies (Lemaitre et al., 1996). The identification of toll like receptors (TLR) in mammals, of which more than 10 different varieties are now recognized, paved the way to understand the importance of the innate immune response to $\mathrm{Ag}$, and the subsequent interactions between the innate and adaptive immune system (Medzhitov et al., 1997). Specially important was the finding by Beutler's group that TLR4 recognizes pathogen-associated molecular patterns (PAMPS) such as those present in the bacterial lipopolysaccharide (LPS; Poltorak et al., 1998). From that point on, the appropriate search and use of adjuvants has acquired a more rational basis (for a review, see Duthie et al., 2011). Other mechanisms of TLR recognition of foreign molecules, such as TLR3 binding of double-stranded RNA present in virus, have been discovered and originated the synthetic adjuvant double-stranded RNA polyriboinosinic-polyribocytidylic acid (poly I:C; Trumpfheller et al., 2008).

\section{$T_{\text {reg: IMPLICATIONS FOR IMMUNOTHERAPY }}$}

Regulatory $\mathrm{T}\left(\mathrm{T}_{\text {reg }}\right)$ cells are a subpopulation responsible for controlling immune homeostasis, maintaining $\mathrm{T}$ cell tolerance to self

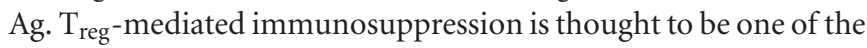
most important mechanisms of tumor immune evasion and probably a main obstacle for effective cancer immunotherapies (Zou, 2006).
$\mathrm{T}_{\text {reg }}$ represent $5-10 \%$ of the CD4 $\mathrm{T}$ cells in peripheral blood (Loser and Beissert, 2012). They are characterized by the constitutive expression of CD25 (IL-2 receptor alpha-chain) and by the expression of the transcription factor forkhead box P3 (FOXP3), crucial for $\mathrm{T}_{\text {reg }}$ development and function (Fontenot et al., 2003).

$\mathrm{T}_{\text {reg }}$ are augmented in peripheral blood of CM patients (Cesana et al., 2006; Jandus et al., 2008; Correll et al., 2010) and they are also highly enriched in the tumor microenvironment (Jacobs et al., 2012) exerting an immunosuppressive function (Javia and Rosenberg, 2003; Vence et al., 2007). In tumor infiltrating lymphocytes (TIL) from different types of tumors, $\mathrm{T}_{\text {reg }}$ were identified as they expressed CD25, FOXP3 and glucocorticoid-induced tumor necrosis factor receptor (GITR) and presented a suppressive function (Wang et al., 2004; Kiniwa et al., 2007).

Curiel et al. (2004) reported that accumulation of $\mathrm{T}_{\text {reg }}$ in the tumor microenvironment was associated with death hazard and reduced survival of ovarian cancer patients. However, the correlation between $\mathrm{T}_{\text {reg }}$ and prognosis in CM patients is still under debate. Some studies showed that an elevated percentage of $\mathrm{T}_{\text {reg }}$ in primary melanoma and metastasis predicted recurrence and reduced overall survival (Miracco et al., 2007; Knol et al., 2011), while others did not found such correlation (Hillen et al., 2008; Ladanyi et al., 2010).

$\mathrm{T}_{\text {reg }}$ can be classified in natural $\mathrm{T}_{\text {reg }}\left(\mathrm{nT}_{\text {reg }}\right)$ and inducible $\mathrm{T}_{\text {reg }}$ $\left(\mathrm{iT}_{\text {reg }}\right) \cdot \mathrm{nT}_{\text {reg }}, \mathrm{CD} 4+/ \mathrm{CD} 25+\mathrm{FOXP} 3+$, are selected by the thymus and are responsible of maintaining peripheral self-tolerance. They mediate immunosuppression by cell contact-dependent mechanisms (Raimondi et al., 2007). $\mathrm{iT}_{\text {reg, }}$ also referred as $\operatorname{Tr} 1$, are induced in the periphery by environmental signals. Their mode of action is through IL-10 and TGF-beta, so they act in a contactindependent way (Chattopadhyay et al., 2005) and they may not express FOXP3. $\mathrm{T}_{\text {reg }}$ present in cancer patients are predominantly $\mathrm{iT}_{\text {reg }}$ (Whiteside, 2012), that mediate stronger suppression and might use additional suppression mechanisms than $\mathrm{nT}_{\text {reg }}$ (Strauss et al., 2007).

$\mathrm{T}_{\text {reg }}$ and $\mathrm{T}$ helper cells can be both stimulated by the same melanoma-associated Ag (Fourcade et al., 2010). Because of this, inactivation or depletion of $\mathrm{T}_{\text {reg }}$ may be useful in combination with vaccination to obtain a successful immunotherapy response. $\mathrm{T}_{\text {reg }}$ depletion therapies include treatment with cyclophosphamide (Ghiringhelli et al., 2007), anti-CD25 antibodies, and toxins fused to anti-CD25 antibodies or IL-2 (Powell et al., 2008; Jacobs et al., 2010), and FOXP3 vaccination (Nair et al., 2007). With the aim of developing efficient $\mathrm{T}_{\text {reg }}$-targeting strategies, it is essential to find new and more accurate markers to characterize $T_{\text {reg }}$.

\section{CTLA-4 AND ITS ROLE IN DOWN-MODULATING THE IMMUNE RESPONSE}

In order to boost the activity of therapeutic cancer vaccines, it is important to understand the mechanisms which counter the building-up of a solid immunity in cancer patients. One of such mechanisms is the presence in T lymphocytes of the inhibitory molecule cytotoxic T-lymphocyte antigen-4 (CTLA-4), a type I transmembrane glycoprotein that presents homology with CD28 (Teft et al., 2006). CTLA-4 is expressed in activated T cells and constitutively in $\mathrm{T}_{\text {reg }}$ and, as CD28, it binds to B7.1 (CD80) and B7.2 (CD86) present in APC, but with greater affinity and 
avidity. CTLA-4 has an inhibitory role in T cell activation, and its expression and localization are tightly regulated in $\mathrm{T}$ cells. After activation, CTLA-4 expression increases, reaching a maximum after 2-3 days, and it is translocated to its active localization at the cell surface (Egen et al., 2002). CTLA-4 function is essential to the maintenance of immune homeostasis and helps tolerance to self Ag by downregulating T cell response and proliferation. CTLA4-deficient mice die from profound lymphoproliferative disease, with multiorgan lymphocytic infiltration, and tissue destruction (Tivol et al., 1995; Waterhouse et al., 1995). However, mixed bone marrow chimeric mice that have both CTLA $-4^{-1-}$ and normal $\mathrm{T}$ cells do not present the lymphoproliferative disorder observed in CTLA-4-deficient mice (Bachmann et al., 1999), suggesting that CTLA-4 function has a non-cell autonomous component acting in trans. Different possibilities have been proposed to explain CTLA4 mechanism of action. In the first place, CTLA- 4 competes with CD28 for its ligands CD80 and CD86. Since both ligands have higher affinity for CTLA-4, it abolishes CD28 signaling, therefore mediating an indirect effect. Besides, CTLA-4 sends cell-intrinsic cis negative signals through its cytoplasmic domain, inhibiting different components of the cell cycle machinery (Greenwald et al., 2002) and blocking TCR and CD28 signaling (Teft et al., 2006). CTLA-4 may also function by disrupting the organization of molecules in the immune synapse (Chambers et al., 2001). Additional potential CTLA-4 functions include upregulation of indolamine 2,3-dioxygenase (IDO) activity in APCs via CD80 and CD86 and regulation of T cell adhesion to APCs (Schneider et al., 2005; Sansom and Walker, 2006). Besides, evidence in mice suggests that CTLA-4 is constitutively expressed in $\mathrm{T}_{\text {reg }}$ and would mediate $\mathrm{T}_{\text {reg }}$ immunosuppression (Takahashi et al., 2000; Wing et al., 2008), since blocking CTLA-4 in $\mathrm{T}_{\text {reg }}$ restrain their ability to inhibit $\mathrm{T}$ effector cell proliferation (Peggs et al., 2009). Recently, another cell extrinsic mechanism for CTLA-4 function was proposed, suggesting that it participates in the removal of costimulatory ligands via trans-endocytosis (Qureshi et al., 2011).

Two different models have been proposed to integrate the stimulatory signals involved in T cell activation and CTLA-4 function, the threshold and the attenuation models (Chambers et al., 2001). According to the threshold model, CTLA- 4 would increase the minimum requirements for $\mathrm{T}$ cell activation by setting a threshold for the quantity and/or quality of TCR signal and/or costimulatory signals (Egen et al., 2002). The attenuation model proposes that CTLA-4 would exert its inhibitory function after T cell stimulation once the cell already entered cycling, and CTLA-4 levels would depend on strength of TCR signal.

\section{CTLA-4 AS THERAPEUTIC TARGET}

Considering CTLA-4 key role in the regulation of $\mathrm{T}$ cell response, blocking antibodies have been developed in order to potentiate anticancer responses. Ipilimumab, a human IgG1 monoclonal antibody (mAb) anti-CTLA-4, and Tremelimumab, another human IgG2 mAb anti-CTLA-4, were tested in clinical trials in patients with CM (Ascierto et al., 2011).

By which mechanism CTLA-4 blocking antibodies exert their function is not completely clear. In murine models, CTLA-4 blockade leads to antitumor cytotoxicity, presenting an increased ratio of CD8: $\mathrm{T}_{\text {reg }}$ in tumor infiltrates (Quezada et al., 2006). Recently it has been proposed that CTLA-4 blockade could enhance memory CD8 T cell response (Pedicord et al., 2011), which could be important in cancer therapy to improve tumor-specific memory CD8 T cells and develop durable anticancer responses. Several early stage clinical trials demonstrated that CTLA-4 blockade alone or in combination with other therapies, as vaccines or chemotherapy, can induce tumor regression in a minority of metastatic CM patients (Hodi et al., 2003; Attia et al., 2005; Ribas et al., 2005, 2009). Hodi et al. (2008) showed that biopsies of metastatic melanoma lesions after ipilimumab administration showed dense infiltration of CD8 T cells, and tumor necrosis correlated with the ratio of infiltrating CD8 T cells/FoxP3 + cells. Blockade of CTLA-4 would promote $\mathrm{T}$ cell proliferation in lymphoid organs that would subsequently lead to an increased T-cell infiltration in most patients (Ribas et al., 2010; Huang et al., 2011). However, tumor infiltration by T cells does not correlate with patient's clinical response (Huang et al., 2011), suggesting that resistance to CTLA-4 blockade could depend on the immunosuppressive mechanisms that the tumor displays.

Last year, as a result of a phase III clinical trial (Hodi et al., 2010), USA FDA approved the use of ipilimumab for treatment of advanced metastatic CM. The antibody therapy, with or without gp100 peptide vaccine, showed improved overall survival compared to gp100 vaccine alone. Toxicity was found in patients treated with ipilimumab, including grades 3-4 immune-related adverse events (irAE) in $10-15 \%$ of patients.

Another phase III study of ipilimumab was performed in patients with previously untreated metastatic CM. In this case, ipilimumab in combination with dacarbazine was compared with dacarbazine plus placebo, showing improved overall survival with the antibody therapy (Robert et al., 2011). Remarkably, the time of ipilimumab to induce tumor remissions may take months, pointing to a different mechanism of action than most chemotherapeutic agents.

\section{OTHER INHIBITORY CORECEPTORS}

In addition, diverse targets are also being studied in order to potentiate antitumor immune response. Programmed (cell) death-1 (PD-1; CD279) is an inhibitory coreceptor which can be expressed in activated T cells, B cells, NK cells, activated monocytes, and DC (Keir et al., 2008). The ligands for PD-1, PD-L1 (B7-H1; CD274), and PD-L2 (B7-DC; CD273) are upregulated in response to inflammation. In fact, the major role of PD- 1 is to limit the activity of $\mathrm{T}$ cells in the periphery during an inflammatory response to infection and autoimmunity (Topalian et al., 2012). The PD-1/PDL1 pathway is important in the development of central and peripheral tolerance to exogenous $\mathrm{Ag}$ at sites of immune privilege, limiting the duration of the normal adaptive immune response (Folkl and Bienzle, 2010). Physiological functions of the PD pathway are altered in cancer (Okazaki and Honjo, 2007). Currently, there are four anti-PD-1 agents in clinical testing for cancer therapy: MDX1106/BMS-936558/ONO-4538; CT-011; MK-3475, and AMP-224 (Topalian et al., 2012). MDX-1106 is a fully human IgG4 mAb that has been tested in a phase I clinical trial on 39 patients with treatment-refractory solid tumors. This mAb showed antitumor activity and was well tolerated. Pharmacodynamic studies indicated a sustained mean occupancy of around $70 \%$ on circulating 
T cells during 2 months. Approximately $12 \%$ of patients suffered grade $\geq 3$ adverse clinical events (Brahmer et al., 2010). A randomized phase II study is currently undergoing to evaluate this $\mathrm{mAb}$ in metastatic renal cell carcinoma. CT-011, a humanized IgG1 mAb, was tested on 17 patients with advanced hematologic malignancies. This anti-PD-1 agent was generally well tolerated (Berger et al., 2008). CT-011 is currently undergoing a phase II clinical trial on metastatic renal cell carcinoma patients.

\section{LOW-DOSE CYCLOPHOSPHAMIDE}

Another way of countering immune suppression is to use low doses of the alkylating agent cyclophosphamide (CTX). Already Berd and Mastrangelo (1988b) utilized low-dose CTX (300 mg/sq m) to diminish immune suppression in CM patients. This immuneenhancing effect of CTX was afterward analyzed in several experimental systems and using different CTX doses. The results obtained, although positive, point to different mechanisms of action. Thus, Ghiringhelli et al. (2004) working on a rat colon carcinoma, demonstrated that a single injection of CTX $(30 \mathrm{mg} / \mathrm{kg})$ determined tumor rejection, and the authors attributed this effect to lymphodepletion of $\mathrm{CD} 4+/ \mathrm{CD} 25+\mathrm{T}_{\text {reg. }}$. In the C57Bl/6J mice/B16 melanoma cells model, Nakahara et al. (2010) found that a single injection of CTX $(150 \mathrm{mg} / \mathrm{kg})$ induced a selective and profound depletion of resident CD8+ DC, and that such depletion diminished the activity of $\mathrm{T}_{\text {reg }}$ and restored concommitant antitumor immunity. Pointing in the same direction, Radojcic et al. (2010) demonstrated that a single injection of CTX $(200 \mathrm{mg} / \mathrm{kg})$ in mice bearing CT26 colon carcinoma would enhance antitumor immunity by resetting $\mathrm{DC}$ homeostasis.

Clinical trials using CTX to enhance antitumor immunity are scarce. Ghiringhelli et al. (2007) used iterative low doses of CTX in advanced cancer patients and demonstrated a strong reduction of circulating $\mathrm{T}_{\text {reg }}$ However, Ellebaek et al. (2012) in a phase II trial with CM patients using metronomic CTX, did not find any reduction in circulating $\mathrm{T}_{\text {reg. }}$. Further clinical trials addressing the role of CTX to enhance antitumor immunity should be examined in carefully designed clinical trials.

\section{WHICH SLEEPING LYMPHOCYTES NEED TO BE AWAKEN TO EXERT ANTITUMOR EFFECT?}

After the observed induction by anti-CTLA- $4 \mathrm{mAb}$ of immune responses against tumors, as well as of autoimmune reactions, the question may be posed if such effects are due to the emergence of effector $\mathrm{T}$ lymphocytes induced de novo by the derepression of $\mathrm{T}_{\text {reg }}$ on APC, or, alternatively, if CD4 and CD8 effector lymphocytes which are blocked in cis by CTLA- 4 are already in the circulation and relieved from this suppression by ipilimumab. Besides, there is yet another question that remains to be answered: CD4 and CD8 cells generated by vaccination absolutely need to have high affinity or avidity toward tumor cells to be active? In this sense, it is important to note that Dutoit et al. (2002) have shown that in preimmune HLA-A2 individuals, up to 1/1.000 CD8 lymphocytes recognized

\section{REFERENCES}

Aris, M., Zubieta, M. R., Colombo, M., Arriaga, J. M., Bianchini, M., Alperovich, M., Bravo, A. I., Barrio, M. M., and Mordoh, J. (2012). and -non-expressing melanoma cells are equally proliferative in tumors and clonogenic in vitro. $J$. Invest. Dermatol. 132, 365-374.
MART-1- and gp100-expressing

MART-1 peptides with low avidity (nM range), as compared to high affinities found for TCR directed to viral Ag (pM range), and that most of the CD8 clones exhibited cross-reactivity toward self-peptides (TCR polyspecificity; Dutoit et al., 2002). However, expansion of the naïve anti-MART-1 CD8 pool does not appear to play a role in tumor regressions induced by ipilimumab, since the outcome of HLA-A2-positive and -negative patients is similar (Wolchok et al., 2010). The polyspecificity of TCR has been studied in more detail in autoimmunity, in which several experimental models are available. In multiple sclerosis and Type 1 Diabetes, polyspecificity of the TCR, characterized by the ability of a single TCR to recognize diverse MHC-peptides, appears to be an intrinsic property of TCR (Liblau et al., 2011).

In the case of cancer, it is not yet known which are the TCR best suited to eliminate tumors in the long range: those with high affinity for a single HLA-peptide complex or those with medium affinity but directed against a variety of targets.

Another question that may be posed is the effective ability of CD8 T cells to lyse tumor cells. In this sense, the different contexts in which tumor cells and T lymphocytes may encounter should be differentiated. In the simplest case, that is, when cytotoxic lymphocytes (CTL) are confronted in vitro to tumor cells, we have shown that clonogenic melanoma cells are effectively lysed by anti-MART-1 and/or anti-gp100 CTL (Aris et al., 2012). However, if such activity is maintained in vivo has not been answered. Large tumors $(>2 \mathrm{~cm})$ are presently considered as an organ, in which complex interactions between the tumor and stroma are established, and in which genomic instability and inflammation play substantial roles in favoring tumor progression. A complex array of immunosuppressive factors is released by tumor cells, building an immunoresistant superstructure (Hanahan and Weinberg, 2000). It is our view that large tumors display a setting in which vaccination has a limited role; the most amenable clinical context to assay antitumor vaccination, would be patients in which the existence of micrometastasis is highly probable. Under such circumstances, the tumor "fortress" building has not been completed, and the immune system has fewer obstacles to surmount. CM patients with stages II and III of the disease could benefit from such therapy. The use of agents which counter immunosuppression, such as ipilimumab, in combination with cancer vaccines, could lead to additive or synergistic responses.

\section{ACKNOWLEDGMENTS}

This work has been supported by grants from the Agencia Nacional de Promoción Científica y Tecnológica (ANPCyT), Fundación Sales, Fundación Cáncer (FUCA), Fundación Pedro F. Mosoteguy, and Fundación María Calderón de la Barca, Argentina. José Mordoh is a member of the Consejo Nacional de Investigaciones Científicas y Técnicas (CONICET), María Laura Lacreu is a fellow of ANPCyT, and Florencia Paula Madorsky-Rowdo is a fellow of CONICET.

Ascierto, P. A., Marincola, F. M., and Ribas, A. (2011). Anti-CTLA4 monoclonal antibodies: the past and the future in clinical application. $J$. Transl. Med. 9, 196.
Attia, P., Phan, G. Q., Maker, A. V., Robinson, M. R., Quezado, M. M., Yang, J. C., Sherry, R. M., Topalian, S. L., Kammula, U. S., Royal, R. E., Restifo, N. P., Haworth, 
L. R., Levy, C., Mavroukakis, S. A., Nichol, G., Yellin, M. J., and Rosenberg, S. A. (2005). Autoimmunity correlates with tumor regression in patients with metastatic melanoma treated with anticytotoxic T-lymphocyte antigen-4. J. Clin. Oncol. 23, 6043-6053.

Aucouturier, J., Ascarateil, S., and Dupuis, L. (2006). The use of oil adjuvants in therapeutic vaccines. Vaccine 24(Suppl. 2), S2-44-S2-45.

Bachmann, M. F., Kohler, G., Ecabert, B., Mak, T. W., and Kopf, M. (1999). Cutting edge: lymphoproliferative disease in the absence of CTLA- 4 is not $\mathrm{T}$ cell autonomous. J. Immunol. 163, 1128-1131.

Barrio, M. M., De Motta, P. T., Kaplan, J., Von Euw, E. M., Bravo, A. I., Chacon, R. D., and Mordoh, J. (2006). A phase I study of an allogeneic cell vaccine (VACCIMEL) with GM-CSF in melanoma patients. J. Immunother. $29,444-454$

Berd, D., and Mastrangelo, M. J. (1988a). Active immunotherapy of human melanoma exploiting the immunopotentiating effects of cyclophosphamide. Cancer Invest. 6 , 337-349.

Berd, D., and Mastrangelo, M. J. (1988b). Effect of low dose cyclophosphamide on the immune system of cancer patients: depletion of $\mathrm{CD} 4+, 2 \mathrm{H} 4+$ suppressor-inducer T-cells. Cancer Res. 48, 1671-1675.

Berger, R., Rotem-Yehudar, R., Slama, G., Landes, S., Kneller, A., Leiba, M., Koren-Michowitz, M., Shimoni, A., and Nagler, A. (2008). Phase I safety and pharmacokinetic study of CT011, a humanized antibody interacting with PD-1, in patients with advanced hematologic malignancies. Clin. Cancer Res. 14, 3044-3051.

Billiau, A., and Matthys, P. (2001). Modes of action of Freund's adjuvants in experimental models of autoimmune diseases. J. Leukoc. Biol. 70, 849-860.

Brahmer, J. R., Drake, C. G., Wollner, I., Powderly, J. D., Picus, J., Sharfman, W. H., Stankevich, E., Pons, A., Salay, T. M., Mcmiller, T. L., Gilson, M. M., Wang, C., Selby, M., Taube, J. M., Anders, R., Chen, L., Korman, A. J., Pardoll, D. M., Lowy, I., and Topalian, S. L. (2010). Phase I study of single-agent antiprogrammed death-1 (MDX-1106) in refractory solid tumors: safety, clinical activity, pharmacodynamics, and immunologic correlates. J. Clin. Oncol. 28, 3167-3175.

Brichard, V., Van Pel, A., Wolfel, T., Wolfel, C., De Plaen, E., Lethe, B., Coulie, P., and Boon, T. (1993).
The tyrosinase gene codes for an antigen recognized by autologous cytolytic T lymphocytes on HLAA2 melanomas. J. Exp. Med. 178, 489-495.

Castle, J. C., Kreiter, S., Diekmann, J., Lower, M., Van De Roemer, N., De Graaf, J., Selmi, A., Diken, M., Boegel, S., Paret, C., Koslowski, M., Kuhn, A. N., Britten, C. M., Huber, C., Tureci, O., and Sahin, U. (2012). Exploiting the mutanome for tumor vaccination. Cancer Res. 72, 1081-1091.

Cesana, G. C., Deraffele, G., Cohen, S., Moroziewicz, D., Mitcham, J., Stoutenburg, J., Cheung, K., Hesdorffer, C., Kim-Schulze, S., and Kaufman, H. L. (2006). Characterization of $\mathrm{CD} 4+\mathrm{CD} 25+$ regulatory $\mathrm{T}$ cells in patients treated with highdose interleukin-2 for metastatic melanoma or renal cell carcinoma. J. Clin. Oncol. 24, 1169-1177.

Chambers, C. A., Kuhns, M. S., Egen, J. G., and Allison, J. P. (2001). CTLA-4-mediated inhibition in regulation of $\mathrm{T}$ cell responses: mechanisms and manipulation in tumor immunotherapy. Annu. Rev. Immunol. 19, 565-594.

Chattopadhyay, S., Chakraborty, N. G., and Mukherji, B. (2005). Regulatory $\mathrm{T}$ cells and tumor immunity. Cancer Immunol. Immunother. 54, 1153-1161.

Chen, Y. T., Scanlan, M. J., Sahin, U., Tureci, O., Gure, A. O., Tsang, S., Williamson, B., Stockert, E., Pfreundschuh, M., and Old, L. J. (1997). A testicular antigen aberrantly expressed in human cancers detected by autologous antibody screening. Proc. Natl. Acad. Sci. U.S.A. 94, 1914-1918.

Chin, L., Garraway, L. A., and Fisher, D. E. (2006). Malignant melanoma: genetics and therapeutics in the genomic era. Genes Dev. 20, 2149-2182.

Chowdhury, R., and Ghosh, S. (2012). Phytol-derived novel isoprenoid immunostimulants. Front. Immunol. 3:49. doi:10.3389/fimmu.2012.00049

Clemente, C. G., Mihm, M. C. Jr., Bufalino, R., Zurrida, S., Collini, P., and Cascinelli, N. (1996). Prognostic value of tumor infiltrating lymphocytes in the vertical growth phase of primary cutaneous melanoma. Cancer 77, 1303-1310.

Correll, A., Tuettenberg, A., Becker, C., and Jonuleit, H. (2010). Increased regulatory $\mathrm{T}$-cell frequencies in patients with advanced melanoma correlate with a generally impaired T-cell responsiveness and are restored after dendritic cell-based vaccination. Exp. Dermatol. 19, e213-e221.

Coulie, P. G., Brichard, V., Van Pel, A., Wolfel, T., Schneider, J., Traversari, C., Mattei, S., De Plaen, E., Lurquin, C., Szikora, J. P., Renauld, J. C., and Boon, T. (1994). A new gene coding for a differentiation antigen recognized by autologous cytolytic T lymphocytes on HLA-A2 melanomas. J. Exp. Med. 180, 35-42.

Curiel, T. J., Coukos, G., Zou, L., Alvarez, X., Cheng, P., Mottram, P., EvdemonHogan, M., Conejo-Garcia, J. R., Zhang, L., Burow, M., Zhu, Y., Wei, S., Kryczek, I., Daniel, B., Gordon, A. Myers, L., Lackner, A., Disis, M. L., Knutson, K. L., Chen, L., and Zou, W. (2004). Specific recruitment of regulatory $\mathrm{T}$ cells in ovarian carcinoma fosters immune privilege and predicts reduced survival. Nat. Med. 10, 942-949.

Dalgleish, A. G. (2011). Therapeutic cancer vaccines: why so few randomised phase III studies reflect the initial optimism of phase II studies. Vaccine 29, 8501-8505.

Dranoff, G., Jaffee, E., Lazenby, A., Golumbek, P., Levitsky, H., Brose, K., Jackson, V., Hamada, H., Pardoll, D., and Mulligan, R. C. (1993). Vaccination with irradiated tumor cells engineered to secrete murine granulocyte-macrophage colonystimulating factor stimulates potent, specific, and long-lasting anti-tumor immunity. Proc. Natl. Acad. Sci. U.S.A. 90, 3539-3543.

Duthie, M. S., Windish, H. P., Fox, C. B., and Reed, S. G. (2011). Use of defined TLR ligands as adjuvants within human vaccines. Immunol. Rev. 239, 178-196.

Dutoit, V., Rubio-Godoy, V., Pittet, M. J., Zippelius, A., Dietrich, P. Y., Legal, F. A., Guillaume, P., Romero, P., Cerottini, J. C., Houghten, R. A., Pinilla, C., and Valmori, D. (2002). Degeneracy of antigen recognition as the molecular basis for the high frequency of naive A2/Melan-a peptide multi$\operatorname{mer}(+) \mathrm{CD} 8(+) \mathrm{T}$ cells in humans. J. Exp. Med. 196, 207-216.

Dutton-Regester, K., and Hayward, N. K. (2012). Reviewing the somatic genetics of melanoma: from current to future analytical approaches. Pigment Cell Melanoma Res. 25, 144154.

Egen, J. G., Kuhns, M. S., and Allison, J. P. (2002). CTLA-4: new insights into its biological function and use in tumor immunotherapy. Nat. Immunol. 3, 611-618.

Eggert, A. A., Schreurs, M. W., Boerman, O. C., Oyen, W. J., De Boer,
A. J., Punt, C. J., Figdor, C. G., and Adema, G. J. (1999). Biodistribution and vaccine efficiency of murine dendritic cells are dependent on the route of administration. Cancer Res. 59, 3340-3345.

Ellebaek, E., Engell-Noerregaard, L., Iversen, T. Z., Froesig, T. M., Munir, S., Hadrup, S. R., Andersen, M. H., and Svane, I. M. (2012). Metastatic melanoma patients treated with dendritic cell vaccination, Interleukin-2 and metronomic cyclophosphamide: results from a phase II trial. Cancer Immunol. Immunother. doi: 10.1007/s00262-012-1242-4

Faure, F., Mantegazza, A., Sadaka, C., Sedlik, C., Jotereau, F., and Amigorena, S. (2009). Long-lasting cross-presentation of tumor antigen in human DC. Eur. J. Immunol. 39, 380-390.

Foley, E. J. (1953). Antigenic properties of methylcholanthrene-induced tumors in mice of the strain of origin. Cancer Res. 13, 835-837.

Folkl, A., and Bienzle, D. (2010). Structure and function of programmed death (PD) molecules. Vet. Immunol. Immunopathol. 134, 33-38.

Fontenot, J. D., Gavin, M. A., and Rudensky, A. Y. (2003). Foxp3 programs the development and function of $\mathrm{CD} 4+\mathrm{CD} 25+$ regulatory $\mathrm{T}$ cells. Nat. Immunol. 4, 330-336.

Fourcade, J., Sun, Z., Kudela, P., Janjic, B., Kirkwood, J. M., El-Hafnawy, T., and Zarour, H. M. (2010). Human tumor antigen-specific helper and regulatory $\mathrm{T}$ cells share common epitope specificity but exhibit distinct $\mathrm{T}$ cell repertoire. J. Immunol. 184, 6709-6718.

Fox, C. B., Baldwin, S. L., Duthie, M. S., Reed, S. G., and Vedvick, T. S. (2011). Immunomodulatory and physical effects of oil composition in vaccine adjuvant emulsions. Vaccine 29, 9563-9572.

Freund, J. (1956). The mode of action of immunologic adjuvants. Bibl. Tuberc. 10, 130-148.

Garg, S., Oran, A., Wajchman, J., Sasaki, S., Maris, C. H., Kapp, J. A., and Jacob, J. (2003). Genetic tagging shows increased frequency and longevity of antigen-presenting, skin-derived dendritic cells in vivo. Nat. Immunol. 4, 907-912.

Ghiringhelli, F., Larmonier, N., Schmitt, E., Parcellier, A., Cathelin, D., Garrido, C., Chauffert, B., Solary, E., Bonnotte, B., and Martin, F. (2004). CD4+CD25 + regulatory T cells suppress tumor immunity but are sensitive to cyclophosphamide which allows immunotherapy of 
established tumors to be curative. Eur. J. Immunol. 34, 336-344.

Ghiringhelli, F., Menard, C., Puig, P. E., Ladoire, S., Roux, S., Martin, F., Solary, E., Le Cesne, A., Zitvogel, L., and Chauffert, B. (2007). Metronomic cyclophosphamide regimen selectively depletes CD4+CD25+ regulatory $\mathrm{T}$ cells and restores $\mathrm{T}$ and NK effector functions in end stage cancer patients. Cancer Immunol. Immunother. 56, 641-648.

Godet, Y., Moreau-Aubry, A., Guilloux, Y., Vignard, V., Khammari, A., Dreno, B., Jotereau, F., and Labarriere, N. (2008). MELOE-1 is a new antigen overexpressed in melanomas and involved in adoptive $\mathrm{T}$ cell transfer efficiency. J. Exp. Med. 205, 2673-2682.

Goldszmid, R. S., Idoyaga, J., Bravo, A. I., Steinman, R., Mordoh, J., and Wainstok, R. (2003). Dendritic cells charged with apoptotic tumor cells induce long-lived protective CD4+ and CD8+ T cell immunity against B16 melanoma. J. Immunol. 171, 5940-5947.

Gray-Schopfer, V., Wellbrock, C., and Marais, R. (2007). Melanoma biology and new targeted therapy. Nature 445, 851-857.

Greenwald, R. J., Oosterwegel, M. A., Van Der Woude, D., Kubal, A., Mandelbrot, D. A., Boussiotis, V. A., and Sharpe, A. H. (2002). CTLA-4 regulates cell cycle progression during a primary immune response. Eur. J. Immunol. 32, 366-373.

Hanahan, D., and Weinberg, R. A. (2000). The hallmarks of cancer. Cell 100, 57-70.

Hersey, P., Menzies, S. W., Halliday, G. M., Nguyen, T., Farrelly, M. L., Desilva, C., and Lett, M. (2004). Phase I/II study of treatment with dendritic cell vaccines in patients with disseminated melanoma. Cancer Immunol. Immunother. 53, 125-134.

Hillen, F., Baeten, C. I., Van De Winkel, A., Creytens, D., Van Der Schaft, D. W., Winnepenninckx, V., and Griffioen, A. W. (2008). Leukocyte infiltration and tumor cell plasticity are parameters of aggressiveness in primary cutaneous melanoma. Cancer Immunol. Immunother. 57, 97-106.

Hodi, F. S., Butler, M., Oble, D. A., Seiden, M. V., Haluska, F. G., Kruse, A., Macrae, S., Nelson, M., Canning, C., Lowy, I., Korman, A., Lautz, D., Russell, S., Jaklitsch, M. T., Ramaiya, N., Chen, T. C., Neuberg, D., Allison, J. P., Mihm, M. C., and Dranoff, G. (2008). Immunologic and clinical effects of antibody blockade of cytotoxic $\mathrm{T}$ lymphocyte-associated antigen 4 in previously vaccinated cancer patients. Proc. Natl. Acad. Sci. U.S.A. 105, 3005-3010.

Hodi, F. S., Mihm, M. C., Soiffer, R. J., Haluska, F. G., Butler, M., Seiden, M. V., Davis, T., HenrySpires, R., Macrae, S., Willman, A., Padera, R., Jaklitsch, M. T., Shankar, S., Chen, T. C., Korman, A., Allison, J. P., and Dranoff, G. (2003). Biologic activity of cytotoxic $\mathrm{T}$ lymphocyte-associated antigen 4 antibody blockade in previously vaccinated metastatic melanoma and ovarian carcinoma patients. Proc. Natl. Acad. Sci. U.S.A. 100, 4712-4717.

Hodi, F. S., O’Day, S. J., Mcdermott, D. F., Weber, R. W., Sosman, J. A., Haanen, J. B., Gonzalez, R., Robert, C., Schadendorf, D., Hassel, J. C., Akerley, W., Van Den Eertwegh, A. J., Lutzky, J., Lorigan, P., Vaubel, J. M., Linette, G. P., Hogg, D., Ottensmeier, C. H., Lebbe, C., Peschel, C., Quirt, I., Clark, J. I., Wolchok, J. D., Weber, J. S., Tian, J., Yellin, M. J., Nichol, G. M., Hoos, A., and Urba, W. J. (2010). Improved survival with ipilimumab in patients with metastatic melanoma. N. Engl. J. Med. 363, 711-723.

Huang, R. R., Jalil, J., Economou, J. S., Chmielowski, B., Koya, R. C., Mok, S., Sazegar, H., Seja, E., Villanueva, A., Gomez-Navarro, J., Glaspy, J. A., Cochran, A. J., and Ribas, A. (2011). CTLA4 blockade induces frequent tumor infiltration by activated lymphocytes regardless of clinical responses in humans. Clin. Cancer Res. 17, 4101-4109.

Huber, M. L., Haynes, L., Parker, C., and Iversen, P. (2012). Interdisciplinary critique of sipuleucel-T as immunotherapy in castrationresistant prostate cancer. J. Natl. Cancer Inst. 104, 273-279.

Hugues, S., Fetler, L., Bonifaz, L., Helft, J., Amblard, F., and Amigorena, S. (2004). Distinct T cell dynamics in lymph nodes during the induction of tolerance and immunity. Nat. Immunol. 5, 1235-1242.

Jacobs, J. F., Nierkens, S., Figdor, C. G., De Vries, I. J., and Adema, G. J. (2012). Regulatory $\mathrm{T}$ cells in melanoma: the final hurdle towards effective immunotherapy? Lancet Oncol. 13, e32-e42.

Jacobs, J. F., Punt, C. J., Lesterhuis, W. J., Sutmuller, R. P., Brouwer, H. M., Scharenborg, N. M., Klasen, I. S., Hilbrands, L. B., Figdor, C. G., De Vries, I. J., and Adema, G. J. (2010). Dendritic cell vaccination in combination with anti-CD25 monoclonal antibody treatment: a phase I/II study in metastatic melanoma patients. Clin. Cancer Res. 16, 5067-5078.

Jandus, C., Bioley, G., Speiser, D. E., and Romero, P. (2008). Selective accumulation of differentiated FOXP3(+) CD4(+) $\mathrm{T}$ cells in metastatic tumor lesions from melanoma patients compared to peripheral blood. Cancer Immunol. Immunother. 57, 1795-1805.

Javia, L. R., and Rosenberg, S. A. (2003). CD4+CD25+ suppressor lymphocytes in the circulation of patients immunized against melanoma antigens. J. Immunother. 26, 85-93.

Kantoff, P. W., Higano, C. S., Shore, N. D., Berger, E. R., Small, E. J., Penson, D. F., Redfern, C. H., Ferrari, A. C., Dreicer, R., Sims, R. B., $\mathrm{Xu}$, Y., Frohlich, M. W., and Schellhammer, P. F. (2010). Sipuleucel$\mathrm{T}$ immunotherapy for castrationresistant prostate cancer. N. Engl. J. Med. 363, 411-422.

Kawakami, Y., Eliyahu, S., Delgado, C. H., Robbins, P. F., Rivoltini, L., Topalian, S. L., Miki, T., and Rosenberg, S. A. (1994a). Cloning of the gene coding for a shared human melanoma antigen recognized by autologous $\mathrm{T}$ cells infiltrating into tumor. Proc. Natl. Acad. Sci. U.S.A. 91, 3515-3519.

Kawakami, Y., Eliyahu, S., Delgado, C. H., Robbins, P. F., Sakaguchi, K., Appella, E., Yannelli, J. R., Adema, G. J., Miki, T., and Rosenberg, S. A. (1994b). Identification of a human melanoma antigen recognized by tumor-infiltrating lymphocytes associated with in vivo tumor rejection. Proc. Natl. Acad. Sci. U.S.A. 91, 6458-6462.

Keir, M. E., Butte, M. J., Freeman, G. J., and Sharpe, A. H. (2008). PD1 and its ligands in tolerance and immunity. Annu. Rev. Immunol. 26, 677-704.

Kensil, C. R., and Kammer, R. (1998) QS-21: a water-soluble triterpene glycoside adjuvant. Expert Opin. Investig. Drugs 7, 1475-1482.

Kiniwa, Y., Miyahara, Y., Wang, H. Y., Peng, W., Peng, G., Wheeler, T. M., Thompson, T. C., Old, L. J., and Wang, R. F. (2007). CD8+ Foxp3+ regulatory $\mathrm{T}$ cells mediate immunosuppression in prostate cancer. Clin. Cancer Res. 13, 6947-6958.

Kirkwood, J. M., Ibrahim, J. G., Sosman, J. A., Sondak, V. K., Agarwala, S. S., Ernstoff, M. S., and Rao, U. (2001). High-dose interferon alfa$2 \mathrm{~b}$ significantly prolongs relapsefree and overall survival compared with the GM2-KLH/QS-21 vaccine in patients with resected stage IIBIII melanoma: results of intergroup trial E1694/S9512/C509801. J. Clin. Oncol. 19, 2370-2380.

Knol, A. C., Nguyen, J. M., Quereux, G., Brocard, A., Khammari, A., and Dreno, B. (2011). Prognostic value of tumor-infiltrating Foxp3+ T-cell subpopulations in metastatic melanoma. Exp. Dermatol. 20, 430-434.

Koebel, C. M., Vermi, W., Swann, J. B., Zerafa, N., Rodig, S. J., Old, L. J., Smyth, M. J., and Schreiber, R. D. (2007). Adaptive immunity maintains occult cancer in an equilibrium state. Nature 450, 903-907.

Ladanyi, A., Mohos, A., Somlai, B., Liszkay, G., Gilde, K., Fejos, Z., Gaudi, I., and Timar, J. (2010). FOXP3+ cell density in primary tumor has no prognostic impact in patients with cutaneous malignant melanoma. Pathol. Oncol. Res. 16, 303-309.

Lemaitre, B., Nicolas, E., Michaut, L., Reichhart, J. M., and Hoffmann, J. A. (1996). The dorsoventral regulatory gene cassette spatzle/Toll/cactus controls the potent antifungal response in Drosophila adults. Cell 86, 973-983.

Liblau, R., Wekerle, H., and Tisch, R. (2011). Cumulative autoimmunity: $\mathrm{T}$ cell clones recognizing several self-epitopes exhibit enhanced pathogenicity. Front. Immunol. 2:47. doi:10.3389/fimmu.2011.00047

Liu, K., Idoyaga, J., Charalambous, A., Fujii, S., Bonito, A., Mordoh, J., Wainstok, R., Bai, X. F., Liu, Y., and Steinman, R. M. (2005). Innate NKT lymphocytes confer superior adaptive immunity via tumor-capturing dendritic cells. J. Exp. Med. 202, 1507-1516.

Livingston, P., Zhang, S., Adluri, S., Yao, T. J., Graeber, L., Ragupathi, G., Helling, F., and Fleisher, M (1997). Tumor cell reactivity mediated by IgM antibodies in sera from melanoma patients vaccinated with GM2 ganglioside covalently linked to KLH is increased by IgG antibodies. Cancer Immunol. Immunother. 43, 324-330.

Loser, K., and Beissert, S. (2012). Regulatory T cells: banned cells for decades. J. Invest. Dermatol. 132, 864-871.

Luiten, R. M., Kueter, E. W., Mooi, W., Gallee, M. P., Rankin, E. M., Gerritsen, W. R., Clift, S. M., Nooijen, W. J., Weder, P., Van De Kasteele, W. F., Sein, J., Van Den Berk, P. C., Nieweg, O. E., Berns, A. M., Spits, H., and De Gast, G. C. (2005). Immunogenicity, including 
vitiligo, and feasibility of vaccination with autologous GM-CSFtransduced tumor cells in metastatic melanoma patients. J. Clin. Oncol. 23, 8978-8991.

Medzhitov, R., Preston-Hurlburt, P., and Janeway, C. A. Jr. (1997). A human homologue of the Drosophila Toll protein signals activation of adaptive immunity. Nature 388, 394-397.

Miracco, C., Mourmouras, V., Biagioli, M., Rubegni, P., Mannucci, S., Monciatti, I., Cosci, E., Tosi, P., and Luzi, P. (2007). Utility of tumourinfiltrating CD25+FOXP3+ regulatory $\mathrm{T}$ cell evaluation in predicting local recurrence in vertical growth phase cutaneous melanoma. Oncol. Rep. 18, 1115-1122.

Morton, D. L., Eilber, F. R., Joseph, W. L., Wood, W. C., Trahan, E., and Ketcham, A. S. (1970). Immunological factors in human sarcomas and melanomas: a rational basis for immunotherapy. Ann. Surg. 172, 740-749.

Morton, D. L., Malmgren, R. A., Holmes, E. C., and Ketcham, A. S. (1968). Demonstration of antibodies against human malignant melanoma by immunofluorescence. Surgery 64, 233-240.

Nair, S., Boczkowski, D., Fassnacht, M., Pisetsky, D., and Gilboa, E. (2007). Vaccination against the forkhead family transcription factor Foxp3 enhances tumor immunity. Cancer Res. 67, 371-380.

Nakahara, T., Uchi, H., Lesokhin, A. M., Avogadri, F., Rizzuto, G. A., Hirschhorn-Cymerman, D., Panageas, K. S., Merghoub, T., Wolchok, J. D., and Houghton, A. N. (2010). Cyclophosphamide enhances immunity by modulating the balance of dendritic cell subsets in lymphoid organs. Blood 115, 4384-4392.

Okazaki, T., and Honjo, T. (2007). PD1 and PD-1 ligands: from discovery to clinical application. Int. Immunol. 19, 813-824.

Palucka, A. K., Ueno, H., Connolly, J., Kerneis-Norvell, F., Blanck, J. P., Johnston, D. A., Fay, J., and Banchereau, J. (2006). Dendritic cells loaded with killed allogeneic melanoma cells can induce objective clinical responses and MART-1 specific CD8+ T-cell immunity. J. Immunother. 29, 545-557.

Pedicord, V. A., Montalvo, W., Leiner, I. M., and Allison, J. P. (2011). Single dose of anti-CTLA-4 enhances CD8+ T-cell memory formation, function, and maintenance. Proc. Natl. Acad. Sci. U.S.A. 108, 266-271.
Peggs, K. S., Quezada, S. A., Chambers, C. A., Korman, A. J., and Allison, J. P. (2009). Blockade of CTLA4 on both effector and regulatory $\mathrm{T}$ cell compartments contributes to the antitumor activity of antiCTLA-4 antibodies. J. Exp. Med. 206, 1717-1725.

Poltorak, A., He, X., Smirnova, I., Liu, M. Y., Van Huffel, C., Du, X., Birdwell, D., Alejos, E., Silva, M., Galanos, C., Freudenberg, M., Ricciardi-Castagnoli, P., Layton, B. and Beutler, B. (1998). Defective LPS signaling in $\mathrm{C} 3 \mathrm{H} / \mathrm{HeJ}$ and $\mathrm{C} 57 \mathrm{BL} / 10 \mathrm{ScCr}$ mice: mutations in Tlr4 gene. Science 282, 2085-2088.

Powell, D. J. Jr., Attia, P., Ghetie, V., Schindler, J., Vitetta, E. S., and Rosenberg, S. A. (2008). Partial reduction of human FOXP3+ CD4 $\mathrm{T}$ cells in vivo after CD25directed recombinant immunotoxin administration. J. Immunother. 31, 189-198.

Prehn, R. T., and Main, J. M. (1957). Immunity to methylcholanthreneinduced sarcomas. J. Natl. Cancer Inst. 18, 769-778.

Quezada, S. A., Peggs, K. S., Curran, M. A., and Allison, J. P. (2006). CTLA4 blockade and GM-CSF combination immunotherapy alters the intratumor balance of effector and regulatory T cells. J. Clin. Invest. 116, 1935-1945.

Qureshi, O. S., Zheng, Y., Nakamura, K., Attridge, K., Manzotti, C., Schmidt, E. M., Baker, J., Jeffery, L. E., Kaur, S., Briggs, Z., Hou, T. Z., Futter, C. E., Anderson, G., Walker, L. S., and Sansom, D. M. (2011). Transendocytosis of CD80 and CD86: a molecular basis for the cell-extrinsic function of CTLA-4. Science 332, 600-603.

Radojcic, V., Bezak, K. B., Skarica, M., Pletneva, M. A., Yoshimura, K., Schulick, R. D., and Luznik, L. (2010). Cyclophosphamide resets dendritic cell homeostasis and enhances antitumor immunity through effects that extend beyond regulatory T cell elimination. Cancer Immunol. Immunother. 59, 137-148.

Raimondi, G., Turner, M. S., Thomson, A. W., and Morel, P. A. (2007). Naturally occurring regulatory $\mathrm{T}$ cells: recent insights in health and disease. Crit. Rev. Immunol. 27, 61-95.

Ribas, A., Benz, M. R., Allen-Auerbach, M. S., Radu, C., Chmielowski, B., Seja, E., Williams, J. L., GomezNavarro, J., Mccarthy, T., and Czernin, J. (2010). Imaging of CTLA4 blockade-induced cell replication with (18)F-FLT PET in patients with advanced melanoma treated with tremelimumab. J. Nucl. Med. 51, 340-346.

Ribas, A., Camacho, L. H., LopezBerestein, G., Pavlov, D., Bulanhagui, C. A., Millham, R., Comin-Anduix, B., Reuben, J. M., Seja, E., Parker, C. A., Sharma, A., Glaspy, J. A., and Gomez-Navarro, J. (2005). Antitumor activity in melanoma and antiself responses in a phase I trial with the anti-cytotoxic $\mathrm{T}$ lymphocyteassociated antigen 4 monoclonal antibody CP-675,206. J. Clin. Oncol. 23, 8968-8977.

Ribas, A., Comin-Anduix, B., Chmielowski, B., Jalil, J., De La Rocha, P., Mccannel, T. A., Ochoa, M. T., Seja, E., Villanueva, A., Oseguera, D. K., Straatsma, B. R., Cochran, A. J., Glaspy, J. A., Hui, L., Marincola, F. M., Wang, E., Economou, J. S., and GomezNavarro, J. (2009). Dendritic cell vaccination combined with CTLA4 blockade in patients with metastatic melanoma. Clin. Cancer Res. 15, 6267-6276.

Robert, C., Thomas, L., Bondarenko, I., O’Day, S. M. D. J., Garbe, C., Lebbe, C., Baurain, J. F., Testori, A., Grob, J. J., Davidson, N., Richards, J., Maio, M., Hauschild, A., Miller, W. H. Jr., Gascon, P., Lotem, M., Harmankaya, K., Ibrahim, R., Francis, S., Chen, T. T., Humphrey, R., Hoos, A., and Wolchok, J. D. (2011). Ipilimumab plus dacarbazine for previously untreated metastatic melanoma. $N$. Engl. J. Med. 364, 2517-2526.

Rosenberg, S. A., Yang, J. C., and Restifo, N. P. (2004). Cancer immunotherapy: moving beyond current vaccines. Nat. Med. 10, 909-915.

Ross, J. S., and Cronin, M. (2011) Whole cancer genome sequencing by next-generation methods. Am. J. Clin. Pathol. 136, 527-539.

Sansom, D. M., and Walker, L. S. (2006). The role of CD28 and cytotoxic Tlymphocyte antigen-4 (CTLA-4) in regulatory T-cell biology. Immunol. Rev. 212, 131-148.

Schijns, V. E., and Lavelle, E. C. (2011). Trends in vaccine adjuvants. Expert Rev. Vaccines 10, 539-550.

Schneider, H., Valk, E., Da Rocha Dias, S., Wei, B., and Rudd, C. E. (2005). CTLA-4 up-regulation of lymphocyte function-associated antigen 1 adhesion and clustering as an alternate basis for coreceptor function. Proc. Natl. Acad. Sci. U.S.A. 102, 12861-12866.

Schuler, G., and Steinman, R. M. (1985). Murine epidermal Langerhans cells mature into potent immunostimulatory dendritic cells in vitro. J. Exp. Med. 161, 526-546.
Schwartzentruber, D. J., Lawson, D. H., Richards, J. M., Conry, R. M., Miller, D. M., Treisman, J., Gailani, F., Riley, L., Conlon, K., Pockaj, B., Kendra, K. L., White, R. L., Gonzalez, R., Kuzel, T. M., Curti, B., Leming, P. D., Whitman, E. D., Balkissoon, J., Reintgen, D. S., Kaufman, H., Marincola, F. M., Merino, M. J., Rosenberg, S. A., Choyke, P., Vena, D., and Hwu, P. (2011). gp100 peptide vaccine and interleukin-2 in patients with advanced melanoma. N. Engl. J. Med. 364, 2119-2127.

Seigler, H. F., Shingleton, W. W., and Pickrell, K. L. (1975). Intralesional BCG, intravenous immune lymphocytes, and immunization with neuraminidase-treated tumor cells to manage melanoma; a clinical assessment. Plast. Reconstr. Surg. 55, 294-298.

Siegel, R., Naishadham, D., and Jemal, A. (2012). Cancer statistics, 2012. CA Cancer J. Clin. 62, 10-29.

Slingluff, C. L. Jr., Petroni, G. R., Olson, W., Czarkowski, A., Grosh, W. W., Smolkin, M., Chianese-Bullock, K. A., Neese, P. Y., Deacon, D. H., Nail, C., Merrill, P., Fink, R., Patterson, J. W., and Rehm, P. K. (2008). Helper T-cell responses and clinical activity of a melanoma vaccine with multiple peptides from MAGE and melanocytic differentiation antigens. J. Clin. Oncol. 26, 4973-4980.

Soiffer, R., Hodi, F. S., Haluska, F., Jung, K., Gillessen, S., Singer, S., Tanabe, K., Duda, R., Mentzer, S., Jaklitsch, M., Bueno, R., Clift, S., Hardy, S., Neuberg, D., Mulligan, R., Webb, I., Mihm, M., and Dranoff, G. (2003). Vaccination with irradiated, autologous melanoma cells engineered to secrete granulocytemacrophage colony-stimulating factor by adenoviral-mediated gene transfer augments antitumor immunity in patients with metastatic melanoma. J. Clin. Oncol. 21, 3343-3350.

Soltysik, S., Wu, J. Y., Recchia, J., Wheeler, D. A., Newman, M. J., Coughlin, R. T., and Kensil, C. R. (1995). Structure/function studies of QS-21 adjuvant: assessment of triterpene aldehyde and glucuronic acid roles in adjuvant function. $\mathrm{Vac}$ cine 13, 1403-1410.

Sondak, V. K., Sabel, M. S., and Mule, J. J. (2006). Allogeneic and autologous melanoma vaccines: where have we been and where are we going? Clin. Cancer Res. 12, 2337s-2341s.

Sonpavde, G., Di Lorenzo, G., Higano, C. S., Kantoff, P. W., Madan, R., and Shore, N. D. (2012). The 
role of sipuleucel- $\mathrm{T}$ in therapy for castration-resistant prostate cancer: a critical analysis of the literature. Eur. Urol. 61, 639-647.

Steinman, R. M., and Cohn, Z. A. (1973). Identification of a novel cell type in peripheral lymphoid organs of mice. I. Morphology, quantitation, tissue distribution. J. Exp. Med. 137, 1142-1162.

Steinman, R. M., and Witmer, M. D. (1978). Lymphoid dendritic cells are potent stimulators of the primary mixed leukocyte reaction in mice. Proc. Natl. Acad. Sci. U.S.A. 75, 5132-5136.

Strauss, L., Bergmann, C., Szczepanski, M., Gooding, W., Johnson, J. T., and Whiteside, T. L. (2007). A unique subset of CD4+CD25highFoxp3+ T cells secreting interleukin-10 and transforming growth factor-betal mediates suppression in the tumor microenvironment. Clin. Cancer Res. 13, 4345-4354.

Takahashi, T., Tagami, T., Yamazaki, S., Uede, T., Shimizu, J., Sakaguchi, N., Mak, T. W., and Sakaguchi, S. (2000). Immunologic self-tolerance maintained by $\mathrm{CD} 25(+) \mathrm{CD} 4(+)$ regulatory $\mathrm{T}$ cells constitutively expressing cytotoxic $\mathrm{T}$ lymphocyte-associated antigen 4. J. Exp. Med. 192, 303-310.

Teft, W. A., Kirchhof, M. G., and Madrenas, J. (2006). A molecular perspective of CTLA-4 function. Annu. Rev. Immunol. 24, 65-97.

Terando, A. M., Faries, M. B., and Morton, D. L. (2007). Vaccine therapy for melanoma: current status and future directions. Vaccine 25(Suppl. 2), B4-B16.

Testori, A., Richards, J., Whitman, E., Mann, G. B., Lutzky, J., Camacho, L., Parmiani, G., Tosti, G., Kirkwood, J. M., Hoos, A., Yuh, L., Gupta, R., and Srivastava, P. K. (2008). Phase III comparison of vitespen, an autologous tumor-derived heat shock protein gp96 peptide complex vaccine, with physician's choice of treatment for stage IV melanoma: the C-10021 study group. J. Clin. Oncol. 26, 955-962.

Tivol, E. A., Borriello, F., Schweitzer, A. N., Lynch, W. P., Bluestone, J. A. and Sharpe, A. H. (1995). Loss of CTLA-4 leads to massive lymphoproliferation and fatal multiorgan tissue destruction, revealing a critical negative regulatory role of CTLA-4. Immunity 3, 541-547.

Topalian, S. L., Drake, C. G., and Pardoll, D. M. (2012). Targeting the PD1/B7-H1(PD-L1) pathway to activate anti-tumor immunity. Curr. Opin. Immunol. 24, 207-212.

Trumpfheller, C., Caskey, M., Nchinda, G., Longhi, M. P., Mizenina, O., Huang, Y., Schlesinger, S. J., Colonna, M., and Steinman, R. M. (2008). The microbial mimic poly IC induces durable and protective CD4+ T cell immunity together with a dendritic cell targeted vaccine. Proc. Natl. Acad. Sci. U.S.A. 105, 2574-2579.

van der Bruggen, P., Traversari, C., Chomez, P., Lurquin, C., De Plaen, E., Van Den Eynde, B., Knuth, A., and Boon, T. (1991). A gene encoding an antigen recognized by cytolytic T lymphocytes on a human melanoma. Science 254, 1643-1647.

Vence, L., Palucka, A. K., Fay, J. W., Ito, T., Liu, Y. J., Banchereau, J., and Ueno, H. (2007). Circulating tumor antigen-specific regulatory $\mathrm{T}$ cells in patients with metastatic melanoma. Proc. Natl. Acad. Sci. U.S.A. 104, 20884-20889.

von Euw, E. M., Barrio, M. M., Furman, D., Bianchini, M., Levy, E. M., Yee, C., Li, Y., Wainstok, R., and Mordoh, J.
(2007). Monocyte-derived dendritic cells loaded with a mixture of apoptotic/necrotic melanoma cells efficiently cross-present gp100 and MART-1 antigens to specific CD8(+) T lymphocytes. J. Transl. Med. 5, 19.

von Euw, E. M., Barrio, M. M., Furman, D., Levy, E. M., Bianchini, M., Peguillet, I., Lantz, O., Vellice, A., Kohan, A., Chacon, M., Yee, C. Wainstok, R., and Mordoh, J. (2008) A phase I clinical study of vaccination of melanoma patients with dendritic cells loaded with allogeneic apoptotic/necrotic melanoma cells. Analysis of toxicity and immune response to the vaccine and of IL-10 -1082 promoter genotype as predictor of disease progression. J. Transl. Med. 6, 6.

Wang, H. Y., Lee, D. A., Peng, G., Guo, Z., Li, Y., Kiniwa, Y., Shevach, E M., and Wang, R. F. (2004). Tumorspecific human CD4+ regulatory $\mathrm{T}$ cells and their ligands: implications for immunotherapy. Immunity 20 107-118.

Wang, R. F., Appella, E., Kawakami, Y., Kang, X., and Rosenberg, S. A. (1996). Identification of TRP-2 as a human tumor antigen recognized by cytotoxic T lymphocytes. J. Exp. Med. 184, 2207-2216.

Waterhouse, P., Penninger, J. M., Timms, E., Wakeham, A., Shahinian, A., Lee, K. P., Thompson, C. B., Griesser, H. and Mak, T. W. (1995). Lymphoproliferative disorders with early lethality in mice deficient in Ctla-4. Science 270, 985-988.

Whiteside, T. L. (2012). What are regulatory T cells (Treg) regulating in cancer and why? Semin. Cancer Biol. doi: 10.1016/j.semcancer.2012.03.004

Wing, K., Onishi, Y., Prieto-Martin, P., Yamaguchi, T., Miyara, M.,
Fehervari, Z., Nomura, T., and Sakaguchi, S. (2008). CTLA-4 control over Foxp3+ regulatory T cell function. Science 322, 271-275.

Wolchok, J. D., Weber, J. S., Hamid, O., Lebbe, C., Maio, M., Schadendorf, D., De Pril, V., Heller, K., Chen, T. T., Ibrahim, R., Hoos, A., and O'Day, S. J. (2010). Ipilimumab efficacy and safety in patients with advanced melanoma: a retrospective analysis of HLA subtype from four trials. Cancer Immun. 10, 9.

Zou, W. (2006). Regulatory T cells, tumour immunity and immunotherapy. Nat. Rev. Immunol. 6, 295-307.

Conflict of Interest Statement: The authors declare that the research was conducted in the absence of any commercial or financial relationships that could be construed as a potential conflict of interest.

Received: 24 February 2012; accepted: 16 April 2012; published online: 04 May 2012.

Citation: Madorsky-Rowdo FP, Lacreu ML and Mordoh J (2012) Melanoma vaccines and modulation of the immune system in the clinical setting: building from new realities. Front. Immun. 3:103. doi: 10.3389/fimmu.2012.00103

This article was submitted to Frontiers in Immunotherapies and Vaccines, a specialty of Frontiers in Immunology. Copyright (ㄷ 2012 Madorsky-Rowdo, Lacreu and Mordoh. This is an openaccess article distributed under the terms of the Creative Commons Attribution Non Commercial License, which permits non-commercial use, distribution, and reproduction in other forums, provided the original authors and source are credited. 